Article

\title{
Sociopsychological Aspects of Butterfly Souvenir Purchasing Behavior at Bantimurung Bulusaraung National Park in Indonesia
}

\author{
Fajri Ansari ${ }^{1}{ }^{(0}$, Yoonjeong Jeong ${ }^{2}$, Indra ASLP Putri ${ }^{1}\left(\mathbb{C}\right.$ and Seong-il Kim ${ }^{2,3, *(1)}$ \\ 1 Environment and Forestry Research and Development Institute of Makassar, Jl, Perintis Kemerdekaan Km \\ 16, PO BOX 1560, Makassar, South Sulawesi 90243, Indonesia; averhoa@gmail.com (F.A.); \\ indra.arsulipp@gmail.com (I.A.P.) \\ 2 Department of Forest Sciences, Seoul National University, Seoul 08826, Korea; yoonjeong522@snu.ac.kr \\ 3 Research Institute of Agriculture and Life Sciences, Seoul National University, Seoul 08826, Korea \\ * Correspondence: seongil@snu.ac.kr; Tel.: +82-2-880-4765
}

Received: 6 March 2019; Accepted: 20 March 2019; Published: 25 March 2019

check for updates

\begin{abstract}
Utilizing butterflies in souvenirs escalates their exploitation, which occurs even with protected species. Visitors affect both tourism sustainability and butterfly populations. Thus, parks must establish visitor management practices to secure tourism, including butterfly-trading activities to provide social and economic benefits, while still maintaining butterfly populations and environmental sustainability. This research examined the relationships between visitors' motivations, environmental attitudes (deontological status, legal compliance, and political activism), and preference regarding butterfly souvenirs. Data were collected using an on-site survey of 455 respondents at Bantimurung Bulusaraung National Park in Indonesia and analyzed using factor analysis, correlation, and logistic regression. Results showed that visitors' motivations were divided into four categories: challenge and freedom, nature appreciation, social relationships, and escape from routine. Visitors showed high deontological status, legal compliance, and political activist attitudes, valued the attributes of butterfly souvenirs highly, and strongly preferred souvenirs with authenticity value. Significant correlations existed among motivation, attitude, and preference for butterfly souvenir attributes. Logistic regression results revealed that with more frequent visits, better souvenir quality, and higher education levels, the possibility of visitors purchasing butterfly souvenirs increased. Prior knowledge regarding regulations prohibiting protected butterfly trading diminished this possibility. This study further discusses how visitors' sociopsychological information can be used to minimize negative impacts caused by overtourism.
\end{abstract}

Keywords: sustainable tourism; tourist motivation; environmental attitude; logistic regression; overtourism

\section{Introduction}

Rapid growth in tourism in the 21st century transformed the sector into one of the world's largest industrial and economic sectors and also brought about swift development of the souvenir procurement industry. All types of goods or products collected by tourists on their vacations are categorized as souvenirs [1]. Currently, souvenirs have become an essential part of the travel industry [2], performing a vital role in tourism development [3]. Conversely, the growth of tourism contributes to the increased demand for souvenirs [4].

Souvenirs are regarded as representing the identities [5,6], symbols [7], and characteristics [8,9] of a tourism destination, and thus play an important role in describing its image $[10,11]$. Souvenirs are 
an influential factor in tourist visitation [12], as they are essential to evoking memories of travelers' previous vacations [1] and increasing the attractiveness of a destination [2].

Tourists are even compelled to hunt $[13,14]$ and purchase $[1,15]$ souvenirs as they become chief requirements of travel [16,17], valuable and potentially tradable items [7], and points of pride in their personal collections [18], commemorating their experiences.

The primary distinguishing feature of souvenirs is that they are made with local and raw materials using natural resources. Since most of the constituents used in handicraft manufacturing have been exploited natural resources, the United Nations Educational, Scientific and Cultural Organization (UNESCO and ITC [19] have emphasized that artisans making souvenirs must utilize sustainable resources as raw materials. Unfortunately, few artisans have paid much attention to sustainable use of natural resources, and using excessive amounts of these resources to meet rapidly increasing demands for souvenirs has threatened some species (e.g., copal trees [20], hemiepiphytes [21], oak wood [22], and mammals [23]). Among various flora and fauna species, butterflies have received more attention than others.

Around 40 million tourists visit butterfly houses and gardens per year [24], and the market is still growing [25]. New [26] stated that butterflies attract people through live exhibits in butterfly houses and gardens, their presence in the wild, and as a commodity for trading, i.e., as specimens for collectors and souvenirs for visitors.

Selling butterflies as souvenirs is not a new practice. In fact, insect trading has a long and complicated history. Butterfly trading has occurred since the post-Renaissance era [24]. The impact of the souvenir trade on butterflies was documented several decades ago by Carvalho and Mielke [27] and cited by Higginbottom [28], indicating that tourists were suspected as the primary cause of the loss of over 50 million butterflies every year in Brazil due to their demand for these insects as souvenirs. Larsen [29] found that approximately 250,000 pieces of butterfly-wing-artworks are traded in the exclusive souvenir shops and the kiosks of major hotels in the capital cities of Africa annually. The author stated that the art usually used common and widespread butterfly species. However, rare butterfly species would also be used occasionally. The negative impacts of visitor behavior on the sustainability of butterflies at tourism destinations were also found in some protected areas [30]. This is in line with the findings of Wang and Shao [31], who also reported that increasing numbers of tourists visiting protected areas and their consumption of souvenirs made with local flora and fauna cause environmental degradation. There is no doubt that the increase in the number of tourists and their souvenir purchases are important and beneficial to local economies in the short-term. However, this can cause serious degradation of both the environment and the tourist experience in the long-term. This phenomenon is called overtourism.

A threat to biodiversity caused by overtourism can also be found at Bantimurung Bulusaraung National Park (Babul NP) in Indonesia. To meet the excessive demands for butterfly souvenirs resulting from the rapid increase in the number of tourists, the local community has gradually come to exploit more butterflies in the forests and surrounding settlements of Babul NP than ever before. Putri [32] stated that there are differences in the number and species of butterflies between areas where forests are subjected to the pressure of butterfly catchers compared to regions where they are not. Putri [33] suspects that the exploitation of butterflies by the community to make souvenirs is the main cause of the butterfly population's decline at Babul NP.

The ecological integrity of butterfly species is fundamental for the sustainable management of Babul NP since protection and preservation of the butterfly population formed the basis for its establishment as a national park [34]. The butterfly is also used as an icon [35] and flagship species [36,37] of Babul NP, making the park "the kingdom of the butterfly" $[35,38,39]$. The existence of abundant butterflies has become its signature attraction, which distinguishes Babul NP from other tourism areas in Indonesia. 
The decrease of the butterfly population due to souvenir demand has emerged as a concerning situation. This crisis not only threatens the sustainability of the park, but also the livelihood of the local stakeholders who act as catchers, gatherers, artisans, and merchants of butterfly souvenirs.

Nevertheless, proper marketing strategies can reduce the negative consequences of overtourism. Research has shown that visitors can threaten the sustainability of tourism through their activities [40]. However, managers may regard visitors as promising agents for improving tourism sustainability [41] by understanding and further manipulating their behaviors. Kim and Weiler [42] stated that segmenting the market using environmental attitudes is an effective and efficient communication strategy for educating and communicating with visitors. As Cochrane [43] reported, Indonesians are motivated to visit national parks to use them as pleasant backdrops for souvenir shopping, eating, and relaxing. In this study, visitors at the Babul NP, who were predominantly Indonesians, were considered as the primary actors causing the demand for butterfly souvenirs.

The goals of this study are threefold: first, to identify visitor motivations, environmental attitudes, and preferences regarding butterfly souvenir attributes at Babul NP; second, to understand the relationships between these variables; and third, to develop a statistical model to predict visitors' butterfly souvenir purchasing behavior using logistic regression.

The research hypotheses of this research are as follows:

H1: Visitors' motivations are related to their environmental attitudes.

H2: Visitors' motivations are related to their preference for the attributes of butterfly souvenirs.

H3: Visitors' environmental attitudes are related to their preference for the attributes of butterfly souvenirs.

\subsection{Sociopsychological Aspects of Butterfly Souvenior Purchasing Behavior}

\subsubsection{Tourist Motivation}

Motivation is defined as the direction of behavior [44,45] or a state of need [46]. Determining visitors' motivations to visit a destination supports tourism managers in identifying visitors' needs and desires, as well as in developing a product, evaluating service quality, improving the location's image, and endorsing activities that fulfill visitors' expectations [47,48]. For these reasons, many researchers have tried to identify various tourist motivations. Scholars have mainly conducted research to understand travelers' destination-specific inclinations [43,49-52]. Kamri and Radam [49] identified tourists' motives for visiting national parks as seeking challenging excursions or locations for social trips, nature tours, and getaways.

\subsubsection{Environmental Attitudes}

Environmental attitudinal variables labeled as deontological status, legal compliance, and political activism were confirmed to impact environmentally friendly purchasing behavior and general behavior toward the environment $[53,54]$.

Deontology was used by Chan, Wong [55] to measure people's ethical judgment to see if they perceived their behavior as being right or wrong. In the context of deontology, judging whether making souvenirs using butterflies is right or wrong might result in different perceptions, depending upon visitors' perspectives. Garcia-Rosell and Moisander [56] stated that a person's deontology might differ depending on whether he/she is anthropocentric, non-anthropocentric, biocentric, or ecocentric.

Legal compliance status indicates the level to which regulations, laws, and rules are obeyed [53,54]. In the national park setting, visitors' obedience to environmental rules is essential in maintaining environmental sustainability. Regarding commodities which originate from living materials in nature, it is crucial to make rules or regulations that govern trade and prevent it from threatening the sustainability of species. The inclusion of species on protection lists can provide benefits for preservation as well as sustainable tourism. [57] 
Bohlen, Schlegelmilch [58] noted that political activism can be inspired by a desire to engage sociopolitically to combat environmental degradation. Evaluating individuals' participation in activities such as media intervention, supporting environmental pressure groups, lobbying political representatives, and boycotting companies has been approved as a means for measuring their political activism [53]. Political activism can further encourage and influence other individuals to participate in similar activities [59].

Visitors who have high environmental attitudes are more likely to modify their behavior to minimize their impact on it, such as by purchasing eco-friendly products and engaging in conservation activities $[53,54]$. Despite this, visitors with high environmental attitudes do not exhibit permanent environmentally responsible behavior due to internal factors such as financial limitations or external influences such as sociopolitical pressures [53], and their behavior may vary depending on whether an environmental issue is general or specific, as well as the on-site conditions they experience [42].

\subsubsection{Preference Regarding Souvenir Attributes}

Attributes were divided into two groups: general attributes and authenticity value. General attributes such as display, quality, and utility values were used to measure visitors' preference for the souvenirs they purchased $[60,61]$.

Nevertheless, there are butterflies that require extraordinary attention from a conservation perspective. Putri [33] found that even though some species are endemic and protected by law, they have still become material for souvenirs. The second group, authenticity value, was divided into four categories related to the ecological characteristics of butterflies. These concerned the preference of visitors for butterflies which were protected by law, rare, and endemic/local species, as well as the authenticity/originality of the butterflies' bodies. The fact that certain species are protected by law indicates that they are threatened. When species are rare or difficult to find, this might imply that their population size is small. Rare status due to decreasing population size indicates that a species is in a vulnerable situation and might be extinct due to over-exploitation [62]. Regarding commodity trading, species protected by law or considered threatened are usually viewed as authentic and thus receive more attention. These attributes, ironically, act to increase the price and demand for them.

Artisans who collected the butterflies from catchers paid different prices according to the species and quality of butterfly. The more complete the bodies/parts and the more perfect the color of the butterflies were, the higher the prices rose [33]. This made catchers prefer to capture mature butterflies so they would collect a higher price. Catching mature butterflies which are still productive threatens their population in the wild. From the managers' perspectives, understanding visitors' choice substitutability regarding purchasing whole bodies vs. certain parts of butterflies would be very interesting because it would answer whether or not broken, dead, or modified butterflies could be used as souvenirs.

It was assumed that there were relationships among the aforementioned variables. The relation between visitors' motivations and their attitudes was reported by Wurzinger and Johansson [63], who found that visitors' environmental attitudes and behavior differed depending on their motivation. Kim and Weiler [42] concluded that visitors' motivations were related to their attitudes and behavior regarding collecting fossils. Kil, Holland [64] also reported that visitors' attitudes significantly affect their motivations.

Attributes of souvenirs and their relationship with visitors' motivations and attitude have also attracted attention in many studies. Kong and Chang [61] reported that visitors' motivations correlated with their perceived importance of the souvenir attributes. Swanson and Horridge [10] also stated that motivation influences perception and preference regarding souvenirs, product features, and store attributes. Understanding sociopsychological characteristics of visitors with respect to souvenir purchasing behavior would help managers properly devise management actions to control visitor behavior and possibly reduce the illegal trade of protected butterflies in the park. 


\section{Materials and Methods}

\subsection{Research Site}

This research was conducted at Bantimurung Bulusaraung National Park (Babul NP) in South Sulawesi Province, Indonesia. Babul NP was declared a national park/conservation area based on Decree No. 398/Menhut/II/2004 by the Indonesian Minister of Forestry, dated 18 October 2004. The total area is approximately 43,750 hectares, which is divided into three major ecosystem types: karst, lowland forest, and lower montane forest. Geographically, the area lies between $119^{\circ} 34^{\prime} 17^{\prime \prime}-119^{\circ} 55^{\prime} 13^{\prime \prime}$ EL and between $4^{\circ} 42^{\prime} 49^{\prime \prime}-5^{\circ} 06^{\prime} 42^{\prime \prime}$ SL (Figure 1). Babul NP spans three administrative regencies (Maros, Pangkep, and Bone), occupying 10 sub-districts and 40 villages [36]. Most of the people (92.2\%) who live in or near Babul NP are farmers with low education levels (84.4\% have only an elementary school education). Additionally, around $65.0 \%$ of them live below the poverty line and have a high level of economic dependence on the Babul NP area [65].

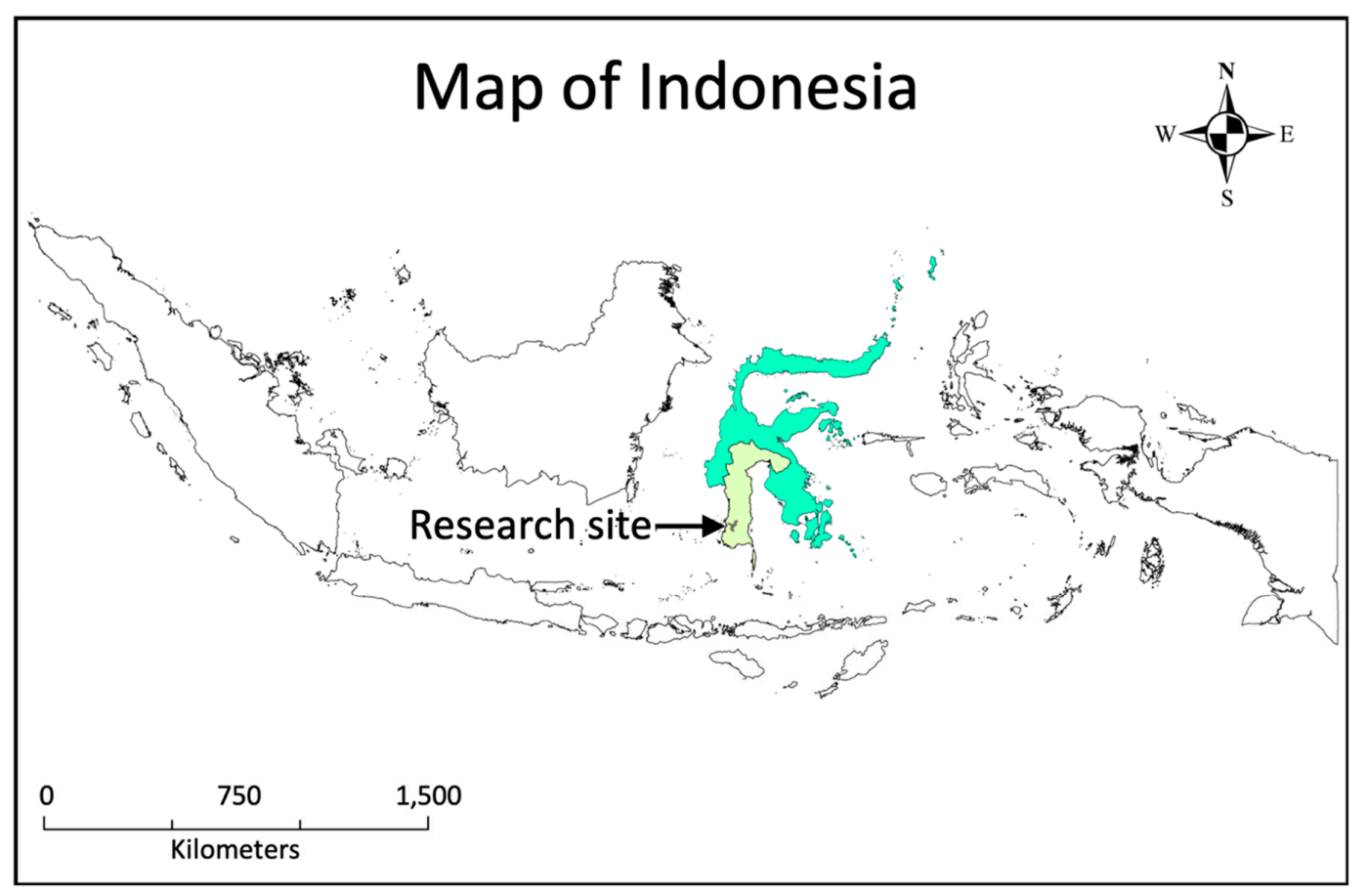

Figure 1. Map of research site.

Babul NP is located in a tropical zone, with temperature ranges from an average low of $21^{\circ} \mathrm{C}$ to an average high of $32{ }^{\circ} \mathrm{C}$. It has high and unique biodiversity, with 709 plant and 728 wildlife species. The latter consists of 33 mammalian, 154 bird, 17 amphibian, and 30 reptilian species, 165 species of Collembola, Pisces, and mollusks, and 300 species of insects, among which 226 are butterflies [66]. There are 51 species of wildlife protected by law and 153 species endemic to Sulawesi. The beauty and uniqueness of the park's butterflies [67], its easily viewed domestic wildlife, and its proximity to major urban centers [43], as well as the natural beauty of its karst tower, waterfalls, rivers, and caves attract tourists on a year-round basis.

\subsection{Data Collection}

Data were collected from a sample of visitors to Babul NP who were chosen based on a convenient sampling method, using self-administered questionnaires. In 2016, over 350,000 individuals visited Babul NP. Using Slovin's formula [68], a sample size was calculated with a minimum of 400 respondents and a $5 \%$ margin of error. The survey was conducted at the entrance of and inside the park from 7 October through 31 October 2017. Based on personal communication with the rangers, it was 
confirmed that the general profile of the visitors stays pretty much the same all through the year. A group of trained assistants administered the survey from 9:30 a.m. to 5:00 p.m. Upon agreeing to participate, visitors were given the questionnaire to complete. Respondents answered after the assistants provided them with a brief explanation regarding the study's purpose and detailed guidance on how to complete the survey. The assistants also helped respondents who were disabled or had low levels of education complete their questionnaires. A total of 455 valid questionnaires was obtained after 487 were distributed.

\subsection{Survey Instrument}

A questionnaire containing 65 items was categorized into six parts. The first part consisted of 20 questions asking respondents to rate their motivations to visit Babul NP using a five-point Likert scale, with the choices being strongly disagree, disagree, moderate, agree, and strongly agree (Table 1). Specific motivation items were extracted from the work of Boxall and Adamowicz [69], who developed statements for measuring motivation for engaging in wilderness recreation in the national park system of the United States.

Table 1. Statements reflecting motivation for wilderness recreation [69].

\begin{tabular}{|c|c|c|c|}
\hline Challenge and Freedom & Nature Appreciation & Social Relationships & Escape from Routine \\
\hline $\begin{array}{ll}\text { - } & \text { To challenge my } \\
\text { skills and abilities } \\
\text { - } & \text { To develop } \\
\text { my skills } \\
\text { - } & \text { To be in charge of } \\
\text { a situation } \\
\text { - } \\
\text { - To feel independent } \\
\text { To feel free from } \\
\text { - } \quad \text { Tociety's restrictions } \\
\text { - } \quad \text { To be alone }\end{array}$ & $\begin{array}{l}\text { To feel close } \\
\text { to nature } \\
\text { To observe the } \\
\text { beauty of nature } \\
\text { To obtain a feeling } \\
\text { of harmony } \\
\text { with nature } \\
\text { To find quiet places } \\
\text { To enjoy the sights, } \\
\text { sounds, and smells } \\
\text { of nature }\end{array}$ & $\begin{array}{l}\text { - To be with my } \\
\text { friends or family } \\
\text { - } \quad \text { To strengthen } \\
\text { relationships with } \\
\text { friends or family } \\
\text { - } \quad \text { To do things with } \\
\text { other people } \\
\text { - To be with people } \\
\text { with } \\
\text { similar interests }\end{array}$ & $\begin{array}{l}\text { - } \quad \text { To escape from the } \\
\text { pressures of work } \\
\text { - } \quad \text { To relieve my tensions } \\
\text { - } \quad \text { To get away from my } \\
\text { everyday routine } \\
\text { - To be away from } \\
\text { other people }\end{array}$ \\
\hline
\end{tabular}

The second part of the questionnaire was composed of 12 items which asked respondents to indicate their environmental attitudes with respect to deontological status, legal compliance, and political activism using a five-point Likert scale (Table 2). The specific statements were extracted from Leonidou et al., (2015) and Leonidou et al., (2010).

Table 2. Environmental attitudes $[53,54]$.

\section{Deontological status}

- I am interested in conserving natural resources

- I reduce unnecessary waste

- I try to create and provide a better living environment for future generations

- I am concerned about the environment for my future personal convenience

\section{Legal compliance}

- I try to avoid committing bribery in my transactions

- I show respect for the law, especially regarding the environment

- I abide by safety laws to protect the environment

- I try to avoid companies that use misleading environmental practices

\section{Political activism}

- I often intervene using the media to combat environmental degradation

- I support environmental pressure groups to combat environmental degradation

- I lobby political representatives to support green issues

- I boycott companies that are not environmentally responsible 
The third part of the questionnaire was composed of 15 statements designed to measure visitors' preferences regarding attributes of butterfly souvenirs using a five-point Likert scale (Table 3). The attributes were separated into two categories: general and authentic. General attributes were assessed using 11 statements which were derived from the works of Kong and Chang [61], Litirell, Baizerman [60], and Turner and Reisinger [70], who developed them to measure visitors' preferences related to souvenirs that they purchased. Authentic attributes were assessed using four statements, and respondents were asked to rate their preferences concerning different types of butterflies used for making souvenirs.

Table 3. Attributes of souvenirs $[60,61,70]$.

\section{General attributes}

- Easy to care for and clean

- Appropriately priced

- Colors are appealing

- Design is appealing

- Easy to pack or carry on a trip

- Can be displayed in the home

- High-quality workmanship

- It is unique

- It can be used or worn

- It can be a good gift

- The Bantimurung name/logo is important

\section{Authentic attributes}

- Souvenirs that are made using a rare species are interesting

- Souvenirs that are made using a protected species are interesting

- Souvenirs that are made using a local/endemic species are interesting

- The authenticity/originality of butterflies' bodies or parts is important

The fourth part of the questionnaire consisted of four inquiries related to characteristics of visitors' travel, such as the primary form of transportation they used to come to Babul NP, the type/number of companions they had, and the number of visits they had made to Babul NP. The fifth part of the questionnaire contained six questions related to souvenir purchasing, such as the reasons why they did or did not buy butterfly souvenirs, their expenditure on butterfly souvenirs, and their knowledge regarding the existence of regulations prohibiting catching and selling/purchasing protected butterflies. The last part of the questionnaire contained eight items asking about respondents' sociodemographic characteristics such as ethnicity, residence, gender, marital status, age, education level, occupation, and income level.

\subsection{Analysis}

Exploratory factor analysis was performed to verify the validity of the items used to assess motivation to visit Babul NP, environmental attitudes, and preferences regarding attributes of butterfly souvenirs. Respondents' answers were subjected to a principle component analysis followed by a varimax orthogonal rotation. Variables that had an Eigenvalue of less than 1.0 and factor loading under 0.5 were eliminated. Through this process, three out of twenty motivation items were eliminated, and four major motivation factors were yielded in accordance with [69] and [49]. Regarding environmental attitudes, one out of twelve items was eliminated, and three major factors were extracted based on [54]. Finally, two out of fifteen items concerning butterfly souvenir attributes were eliminated, and four major factors were extracted. Reliability analysis (Cronbach's alpha) was then computed, respectively, to confirm the internal consistency of the items with each dimension. 
Subsequently, correlation analysis was conducted to test the three hypotheses of this research by determining correlational relationships among the following three groups of variables: motivation to visit Babul NP, attitudes, and preferences regarding the attributes of butterfly souvenirs.

Finally, regression analysis was conducted to determine which variables influenced the visitors' decision to purchase butterfly souvenirs. More specifically, logistic regression analysis was chosen due to the binary nature of the dependent variable (whether the respondent purchased butterfly souvenirs). Visitors were asked, "Did you purchase the butterfly souvenirs at Babul NP?" As described in the Results section of this study, approximately $50.8 \%$ of the respondents indicated that they had purchased butterfly souvenirs, with $49.2 \%$ responding that they had never done so.

The dependent variable (PURCHASE) was coded 1 for respondents who had bought butterfly souvenirs at Babul NP and 0 for those who responded that they had not. There were 15 independent variables in the preliminary model (i.e., deontological status, legal compliance, political activism, display value, authenticity value, quality value, utility value, knowledge of regulations regarding catching protected butterflies, knowledge of regulations governing purchasing/selling souvenirs made with protected butterflies, number of visits to Babul NP, gender, age, marital status, number of companions, and education level). Respondents' motivations to visit Babul NP, environmental attitudes, and preferences concerning butterfly souvenirs were assessed using 5-point Likert scales, as mentioned previously. Knowledge of regulations regarding catching protected butterflies was coded 0 for no (i.e., "I did not know about them") and 1 for yes (i.e., "I knew about them"). The same coding rule was applied to knowledge concerning purchasing/selling souvenirs made from protected butterflies. Gender was coded 0 for female and 1 for male. Marital status was coded 0 for single and 1 for married. Age, number of visits, and number of companions were indicated with numeric scales. Education level was conveyed using ordinal scales reflecting nine levels, from none to master/PhD degree. Monthly income was also indicated using ordinal scales reflecting three levels: less than 70 USD, 70-210 USD, and above 210 USD. Stepwise selection with backward elimination of predictors from the initial model was applied. Consequently, 10 variables were eliminated. The detailed results are described below. Analysis was done using SPSS 24.0 and R 3.5.2.

\section{Results}

\subsection{Visitors' Socioeconomic Chracteristics}

Among the 455 respondents who completed the survey, $43.5 \%$ were male and $56.5 \%$ were female, and $63.5 \%$ were single and $36.5 \%$ were married. Most respondents were aged 20-39 (58.9\%), 25\% were under 20, and only $8.6 \%$ were older than 50 . Education level was quite diverse and relatively high: $22.0 \%$ of respondents were high school graduates, $24.6 \%$ were university students, $31.6 \%$ had bachelor's degrees, and $4.4 \%$ were post-graduate degree holders. Regarding occupation, most respondents were students $(41.3 \%)$, followed by company employees (17.7\%), civil servants $(14.7 \%)$, and those who were self-employed (13.0\%). A total of $47.7 \%$ of respondents made less than $\operatorname{Rp~1,000,000~(about~} 70$ USD) per month. The percentages of respondents who earned Rp 1,000,000-Rp 3,100,000 (70-210 USD) or more than $\operatorname{Rp} 3,100,000$ (210 USD) per month were $24.6 \%$ and $27.7 \%$, respectively (the per capita income of Indonesia was 3847 USD in 2017 [71]). However, considering Indonesia's per capita income and the respondents' high levels of education, it was hard to accept the result indicating that over half of the respondents had annual incomes below 1000 USD. For this reason, respondents' income and expenditure variables were excluded from further analysis.

Approximately $38.0 \%$ of respondents visited the park with their friends, and $33.0 \%$ came with their families. Around $3.7 \%$ visited alone, and $7.5 \%$ were accompanied only by their spouses. Most respondents came with groups of $2-9$ people (50.6\%) or larger (28.3\% visited with $10-49$ people). Interestingly, $10.1 \%$ of respondents came to the park with more than 50 people. Only $1.8 \%$ visited alone, and $9.2 \%$ came with one person. 
The percentage of first-time visitors was close to that of those who had come to the park more than five times, at $31.0 \%$ and $33.2 \%$, respectively. Similarly, the percentage of visitors who were at the park for the second time (12.5\%) was almost equal to that of those who had visited it three times $(12.1 \%)$.

As many as $73.8 \%$ of respondents admitted that they did not know about the existence of regulations prohibiting catching protected butterflies. An even larger portion (80.7\%) of respondents claimed they did not know whether there were regulations forbidding selling and purchasing protected butterflies.

Among the 455 respondents, half (50.8\%) claimed that they had purchased butterfly souvenirs, while $49.2 \%$ claimed that they had never done so. Respondents bought souvenirs for several reasons. Most (51.5\%) purchased them as gifts for other people, and $22.9 \%$ bought them because they wanted butterfly souvenirs to remind them of their trip. The remaining reasons included "no other items to purchase," "just for fun," and "no specific reason." Most respondents (69.2\%) spent less than Rp 100,000 (approximately 7 USD) to purchase the souvenirs. About $29.9 \%$ spent around Rp 100,000-Rp 500,000 (approximately 7-35 USD), while $0.9 \%$ spent more than Rp 500,000 (approximately 35 USD).

Respondents were asked to rate their preferences regarding souvenir attributes. The result showed that most agreed with the overall statements indicating that they had an interest in or preference for purchasing even those souvenirs that were made with protected, rare, and endemic species of butterflies. Respondents also showed similar preferences for authentic/original butterflies that had not been modified and ones that had been assembled using parts of other butterflies.

\subsection{Motivation}

Four factors were extracted from the factor analysis: (a) challenge and freedom, (b) nature appreciation, (c) social relationships, and (d) escape from routine. Factor labels followed the terms that had been used by [69] and [49]. Table 4 shows the loading values of the motivation items. The four factor dimensions explained $56.2 \%$ of the total variance. Among them, challenge and freedom emerged as the most important motivation factor (17.3\% of the total variance) and escape from routine was the least important (11.1\%).

Table 4. Refining items regarding motivation to visit.

\begin{tabular}{|c|c|c|c|c|}
\hline \multirow{2}{*}{ Items } & \multicolumn{4}{|c|}{ Factors } \\
\hline & $\begin{array}{l}\text { Challenge \& } \\
\text { Freedom }\end{array}$ & $\begin{array}{c}\text { Nature } \\
\text { Appreciation }\end{array}$ & $\begin{array}{c}\text { Social } \\
\text { Relationships }\end{array}$ & $\begin{array}{l}\text { Escape from } \\
\text { Routine }\end{array}$ \\
\hline To develop my skills & 0.792 & & & \\
\hline To feel independent & 0.786 & & & \\
\hline To challenge my skills and abilities & 0.772 & & & \\
\hline To feel free from society's restrictions & 0.664 & & & \\
\hline To be alone & 0.557 & & & \\
\hline To be in charge of a situation & 0.500 & & & \\
\hline $\begin{array}{l}\text { To enjoy the sights, sounds, and smells of } \\
\text { nature }\end{array}$ & & 0.852 & & \\
\hline To feel close to nature & & 0.804 & & \\
\hline To observe the beauty of nature & & 0.786 & & \\
\hline To obtain a feeling of harmony with nature & & 0.585 & & \\
\hline To do things with other people & & & 0.809 & \\
\hline $\begin{array}{l}\text { To strengthen relationships with friends or } \\
\text { family }\end{array}$ & & & 0.699 & \\
\hline To be with people of similar interests & & & 0.657 & \\
\hline To be with my friends or family & & & 0.599 & \\
\hline To get away from everyday routine & & & & 0.803 \\
\hline To escape from the pressures of work & & & & 0.780 \\
\hline To relieve my tensions & & & & 0.639 \\
\hline Eigen value & 2.938 & 2.722 & 2.012 & 1.891 \\
\hline Proportion of variance & 0.173 & 0.160 & 0.118 & 0.111 \\
\hline Cronbach's alpha & 0.787 & 0.785 & 0.675 & 0.656 \\
\hline
\end{tabular}




\subsection{Attributes of Souvenirs}

Four factors were extracted from the factor analysis: (a) display value, (b) authenticity value, (c) quality value, and (d) utility value. Table 5 shows the loading values of the items. The four factor dimensions explained $71.4 \%$ of the total variance. Among them, display value emerged as the most important attribute factor ( $23.4 \%$ of the total variance), and utility value was the least important $(13.1 \%)$.

Table 5. Refining items regarding souvenirs' attributes.

\begin{tabular}{|c|c|c|c|c|}
\hline \multirow{2}{*}{ Items } & \multicolumn{4}{|c|}{ Factors } \\
\hline & Display Value & Authenticity Value & Quality Value & Utility Value \\
\hline Easy to pack or carry on a trip & 0.788 & & & \\
\hline Colors are appealing & 0.756 & & & \\
\hline Can be displayed in the home & 0.720 & & & \\
\hline Design is appealing & 0.717 & & & \\
\hline $\begin{array}{l}\text { Souvenirs that are made using protected } \\
\text { species are interesting }\end{array}$ & & 0.837 & & \\
\hline $\begin{array}{l}\text { Souvenirs that are made using local species } \\
\text { are interesting }\end{array}$ & & 0.751 & & \\
\hline $\begin{array}{l}\text { Souvenirs that are made using rare species } \\
\text { are interesting }\end{array}$ & & 0.750 & & \\
\hline $\begin{array}{l}\text { Authenticity of butterfly's body or body } \\
\text { parts is important }\end{array}$ & & 0.641 & & \\
\hline It can be used or worn & & & 0.797 & \\
\hline It is unique & & & 0.677 & \\
\hline High-quality workmanship & & & 0.529 & \\
\hline Appropriately priced & & & & 0.786 \\
\hline Easy to care for and clean & & & & 0.749 \\
\hline Eigen value & 3.048 & 2.646 & 1.865 & 1.703 \\
\hline Proportion of variance & 0.234 & 0.204 & 0.143 & 0.131 \\
\hline Cronbach's alpha & 0.809 & 0.814 & 0.830 & 0.714 \\
\hline
\end{tabular}

\subsection{Attitude of Visitors}

Three factors were extracted from the factor analysis: (a) legal compliance, (b) deontological status, and (c) political activism. Names of the factors were determined based on [54]. Table 6 shows the loading values of the environmental attitude items. The three factor dimensions explained $57.3 \%$ of the total variance. Among them, legal compliance emerged as the most important environmental attitude factor (20.2\% of the total variance), followed by deontological status (19.1\%) and political activism (18.4\%).

Table 6. Refining items regarding environmental attitudes.

\begin{tabular}{lccc}
\hline \multicolumn{1}{c}{ Items } & \multicolumn{1}{c}{ Factors } \\
\cline { 2 - 3 } & Legal Compliance & Deontological Status & Political Activism \\
\hline $\begin{array}{l}\text { I show respect for the law, especially } \\
\text { concerning the environment }\end{array}$ & 0.730 & \\
$\begin{array}{l}\text { I abide by safety laws to protect the } \\
\text { environment }\end{array}$ & 0.722 & \\
$\begin{array}{l}\text { I try to avoid committing bribery in my } \\
\text { transactions }\end{array}$ & 0.639 & \\
$\begin{array}{l}\text { I try to avoid companies that use } \\
\text { misleading environmental practices }\end{array}$ & 0.563 & \\
\hline
\end{tabular}


Table 6. Cont.

\begin{tabular}{|c|c|c|c|}
\hline \multirow{2}{*}{ Items } & \multicolumn{3}{|c|}{ Factors } \\
\hline & Legal Compliance & Deontological Status & Political Activism \\
\hline $\begin{array}{l}\text { I try to create and provide a better living } \\
\text { environment for future generations }\end{array}$ & & 0.794 & \\
\hline $\begin{array}{l}\text { I am interested in conserving natural } \\
\text { resources }\end{array}$ & & 0.788 & \\
\hline I reduce unnecessary waste & & 0.581 & \\
\hline $\begin{array}{l}\text { I support environmental pressure } \\
\text { groups to combat environmental } \\
\text { degradation }\end{array}$ & & & 0.713 \\
\hline $\begin{array}{l}\text { I lobby political representatives to } \\
\text { support green issues }\end{array}$ & & & 0.680 \\
\hline $\begin{array}{l}\text { I often intervene using the media to } \\
\text { combat environmental degradation }\end{array}$ & & & 0.635 \\
\hline $\begin{array}{l}\text { I boycott companies that are not } \\
\text { environmentally responsible }\end{array}$ & & & 0.631 \\
\hline Eigen value & 2.224 & 2.109 & 2.024 \\
\hline Proportion of variance & 0.202 & 0.191 & 0.184 \\
\hline Cronbach's alpha & 0.689 & 0.733 & 0.676 \\
\hline
\end{tabular}

\subsection{Results of Hypotheses Tests}

The first hypothesis was that visitors' motivations are correlated with their environmental attitudes (Table 7). All four motivations-challenge and freedom, nature appreciation, social relationships, and escape from routine-were significantly correlated to deontological status, legal compliance, and political activism. Based on the results, the first hypothesis was accepted.

Table 7. Correlation of motivations and environmental attitudes.

\begin{tabular}{cccccc}
\hline & & \multicolumn{4}{c}{ Motivation } \\
\cline { 3 - 6 } & & $\begin{array}{c}\text { Challenge \& } \\
\text { Freedom }\end{array}$ & $\begin{array}{c}\text { Nature } \\
\text { Appreciation }\end{array}$ & $\begin{array}{c}\text { Social } \\
\text { Relationship }\end{array}$ & $\begin{array}{c}\text { Escape from } \\
\text { Routine }\end{array}$ \\
\hline Deontological & Pearson's $r$ & $0.135^{* *}$ & $0.394^{* *}$ & $0.359^{* *}$ & $0.158^{* *}$ \\
status & $p$-value & 0.004 & 0.000 & 0.000 & 0.001 \\
Legal & Pearson's $r$ & $0.127^{* *}$ & $0.376^{* *}$ & $0.326^{* *}$ & $0.163^{* *}$ \\
compliance & $p$-value & 0.007 & 0.000 & 0.000 & 0.000 \\
Political & Pearson's $r$ & $0.252^{* *}$ & $0.342^{* *}$ & $0.358^{* *}$ & $0.254^{* *}$ \\
activism & $p$-value & $0.000^{* *}$ & 0.000 & 0.000 & 0.000 \\
\hline \multicolumn{2}{c}{} & \multicolumn{2}{c}{$p<0.01}$.
\end{tabular}

The second hypothesis was that visitors' motivations to visit Babul NP are correlated to their preferences for the attributes of butterfly souvenirs. The result in Table 8 shows that most of the motivations had a significant correlation with the four types of butterfly souvenir attributes except the motivation of escape from routine. This motivation factor had a significant correlation to display and utility value but not to authenticity or quality value. Based on the results, it was concluded that the second hypothesis stating that visitors' motivations to visit Babul NP are correlated to their preferences for the attributes of butterfly souvenirs was partially accepted. 
Table 8. Correlation of motivations and souvenir attributes.

\begin{tabular}{cccccc}
\hline & & \multicolumn{4}{c}{ Motivation } \\
\cline { 3 - 5 } & & $\begin{array}{c}\text { Challenge } \& \\
\text { Freedom }\end{array}$ & $\begin{array}{c}\text { Nature } \\
\text { Appreciation }\end{array}$ & $\begin{array}{c}\text { Social } \\
\text { Relationship }\end{array}$ & $\begin{array}{c}\text { Escape from } \\
\text { Routine }\end{array}$ \\
\hline \multirow{2}{*}{ Display value } & Pearson's $r$ & $0.229^{* *}$ & $0.340^{* *}$ & $0.316^{* *}$ & $0.170^{* *}$ \\
Authenticity & $p$-value & 0.000 & 0.000 & 0.000 & 0.000 \\
value & Pearson's $r$ & $0.263^{* *}$ & $0.149^{* *}$ & $0.201^{* *}$ & 0.064 \\
Quality value & $p$-value & 0.000 & 0.001 & 0.000 & 0.176 \\
& Pearson's $r$ & $0.294^{* *}$ & $0.296^{* *}$ & $0.333^{* *}$ & 0.0813 \\
Utility value & $p$-value & 0.000 & 0.000 & 0.000 & 0.083 \\
& Pearson's $r$ & $0.268^{* *}$ & $0.203^{* *}$ & $0.268^{* *}$ & $0.115^{*}$ \\
& $p$-value & 0.000 & 0.000 & 0.000 & 0.014 \\
\hline
\end{tabular}

The third hypothesis was that visitors' environmental attitudes are correlated to their preferences for the four types of butterfly souvenir attributes. The correlation analysis result showed that each factor of environmental attitudes was correlated to various types of butterfly souvenir attributes (Table 9). Deontological status and political activism were significantly correlated to the display, quality, and utility value attributes, but not to authenticity value. Legal compliance only had a significant correlation with display and quality value attributes. Based on the results, it was concluded that the third hypothesis was partially accepted.

Table 9. Correlation of environmental attitudes and souvenir attributes.

\begin{tabular}{ccccc}
\hline & & \multicolumn{3}{c}{ Environmental Attitudes } \\
\cline { 3 - 4 } & & Deontological Status & Legal Compliance & Political Activism \\
\hline \multirow{2}{*}{ Display value } & Pearson's $r$ & $0.129^{* *}$ & $0.144^{* *}$ & $0.151^{* *}$ \\
& $p$-value & 0.006 & 0.002 & 0.001 \\
Authenticity value & Pearson's $r$ & 0.045 & 0.016 & 0.076 \\
& $p$-value & 0.339 & 0.732 & 0.105 \\
Quality value & Pearson's $r$ & $0.148^{* *}$ & $0.092^{*}$ & $0.110^{*}$ \\
& $p$-value & 0.002 & 0.049 & 0.019 \\
Utility value & Pearson's $r$ & $0.108^{*}$ & 0.018 & $0.093^{*}$ \\
& $p$-value & 0.020 & 0.701 & 0.048 \\
\hline
\end{tabular}

\subsection{Logistic Regression}

To select variables for the logistic regression model, the exploratory model having 15 independent variables was modified by dropping the variables using stepwise selection with backward elimination. Consequently, seven variables-political activism, authenticity value, quality value, knowledge of regulations regarding catching protected butterflies, knowledge of regulations governing purchasing/selling protected butterflies, number of visits, and education level—remained (Table 10). Based on these seven variables, the logistic regression equation can be determined as follows:

Ln P/1-P $=-5.569-0.266$ Political activism +0.318 Authenticity value +0.820 Quality value +0.592 Knowledge of regulations regarding catching protected butterflies -0.865 Knowledge of regulations governing purchasing/selling protected butterflies +0.290 Number of visits +0.308 Education level 
Table 10. Variables that influence the decision to purchase.

\begin{tabular}{|c|c|c|c|c|c|}
\hline Variable & Coefficient Estimate & Standard Error & z-Value & Significance & Odds Ratio \\
\hline \multicolumn{6}{|l|}{ Dependent } \\
\hline \multicolumn{6}{|l|}{ Purchase } \\
\hline Intercept & -5.569 & 1.021 & -5.453 & 0.000 & 0.004 \\
\hline \multicolumn{6}{|l|}{ Independent } \\
\hline Political activism & -0.266 & 0.154 & -1.723 & 0.085 & 0.766 \\
\hline Authenticity value & 0.318 & 0.146 & 2.179 & $0.029 *$ & 1.374 \\
\hline Quality value & 0.820 & 0.170 & 4.834 & $0.000 * *$ & 2.270 \\
\hline $\begin{array}{l}\text { Knowledge of catching } \\
\text { regulation }\end{array}$ & 0.592 & 0.382 & 1.552 & 0.121 & \\
\hline $\begin{array}{l}\text { Knowledge of purchasing } \\
\text { regulation }\end{array}$ & -0.865 & 0.424 & -2.041 & 0.041 * & 0.421 \\
\hline Number of visits & 0.290 & 0.052 & 5.552 & $0.000 * *$ & 1.336 \\
\hline Education level & 0.308 & 0.129 & 2.385 & $0.017^{*}$ & 1.361 \\
\hline \multicolumn{6}{|l|}{ Diagnostics } \\
\hline$-2 \log$ likelihood & \multicolumn{5}{|c|}{539.02} \\
\hline Nagelkerke's pseudo- $\mathrm{R}^{2}$ & \multicolumn{5}{|c|}{0.243} \\
\hline $\begin{array}{l}\text { Hosmer and Lemeshow's } \\
\text { goodness-of-fit ( } p \text {-value) }\end{array}$ & \multicolumn{5}{|c|}{$8.977(0.344)$} \\
\hline Percentage classified correctly & \multicolumn{5}{|c|}{59.089} \\
\hline
\end{tabular}

The coefficient for political activism was negative, showing that the odds of the respondents indicating they would purchase butterfly souvenirs decreased if they had a high desire to engage in sociopolitical activities to combat environmental degradation. The coefficients for respondents' preferences for both authenticity and quality values were significantly positive. Based on this result, it can be easily expected that visitors would be more likely to purchase authentic and high-quality butterfly souvenirs. The coefficient for having knowledge of regulations governing purchasing/selling protected butterflies was negative, as expected, and significant at the 0.05 level. Meanwhile, surprisingly, the coefficient for having knowledge of regulations regarding catching protected butterflies was positive. However, it was not found to be statistically significant. The coefficients for number of visits and education level were significantly positive, as well. One explanation may be that respondents with higher levels of education would have relatively high levels of disposable income and scientific interest in butterflies.

A total of 455 observations were used in the logistic regression model. The model was diagnosed as adequate, as the Hosmer and Lemeshow's goodness-of-fit test totaled 8.977 with a significance level of 0.344. The proportion of variance explained (Nagelkerke's pseudo R2) was 0.243 . The classification table indicated that $59.089 \%$ of the predicted outcomes matched the observed ones. This meant that the model could predict nearly $60 \%$ of visitors' butterfly souvenir purchasing behaviors.

\section{Discussion}

The results revealed relationships between visitors' attitudes and three dimensions of souvenir attributes. The significant correlations among these variables indicated that visitors of Babul NP with higher deontological status, legal compliance, and political activism preferred butterfly souvenirs more when they possessed various values, including authenticity.

Surprisingly enough, correlation analysis showed that political activism had no significant relationship with authenticity value. This demonstrated that even though some visitors had higher political activist attitudes, they still wanted souvenirs made using protected, endemic, and rare species, as well as authenticity/originality of the butterflies' bodies or body parts.

Based on observations and communication with visitors, however, these phenomena can be explained by the fact that they received incorrect information about butterfly souvenirs. Most of the visitors heard and trusted that the butterflies came from butterfly farms and not from the natural environment, or that sellers used carcasses/dead butterflies found in nature. This incorrect information allowed visitors to condone their transactions, as they thought it was just as appropriate to use the 
carcasses as it was to let them decompose naturally. It also became obvious that most of the visitors thought that these purchases did not decrease the population of butterflies in the park.

Conversely, visitors with higher deontological status and legal compliance did not have a preference regarding souvenirs using authentic/original butterfly bodies or body parts. Visitors with higher deontological status, according to Garcia-Rosell and Moisander [56], believe in the principle that humans have a moral obligation to protect all values, including faunae, florae, and their ecosystem. Hence, they may not want souvenirs made using protected, endemic, or rare species with complete authentic/original components. Similarly, visitors with higher legal compliance are likely to obey the law and rules, making them stay away from souvenirs illegally made from protected and endemic species.

Furthermore, related to having knowledge of rules/laws regarding protected species, as many as $73.8 \%$ of respondents admitted to not knowing about the existence of regulations that prohibit catching protected butterflies. Similarly, $80.7 \%$ of respondents claimed to not know about regulations prohibiting butterfly trading. Unfortunately, no information had been made accessible in the park regarding legal actions taken to preserve butterflies.

\section{Conclusions and Implications}

The motivations of individuals for visiting Babul NP can be properly divided into four categories: challenge and freedom, escape from routine, nature appreciation, and social relationships. Additionally, visitors' attitudes can be classified into three groups: deontological status, legal compliance, and political activism. This underpins the findings of the previous studies and thus confirms the theoretical framework concerning visitor motivation and attitude regarding this national park.

It has been well reported that attitudes associated with higher deontological status, legal compliance, and political activism positively influence overall environmental attitude, and thus are conductive to eco-friendly behavior [54]. Visitors of Babul NP were found to have relatively high environmental attitudes, and these attitudes were noted to be significantly related to all of their motivations to visit. This indicates that visitors to the park can be considered advocates of the sustainability of butterflies. Furthermore, this scenario supports the effort of preserving butterflies and can be used as a foundation for arranging strategies to protect butterfly populations and creating priority management policies.

The result of this research contributes to the body of research on the factors affecting butterfly souvenir purchasing, which is a rarely investigated topic. Individuals with higher political activism attitudes are less likely to purchase butterflies. However, when people prefer authenticity and quality values regarding butterflies, they tend to purchase them more. Individuals possessing knowledge of regulations governing trading protected butterflies tend not to purchase these insects. Visitation characteristics such as one's number of visits to the park and education level positively increase an individual's purchasing probability, possibly because of having more disposable income and a scientific interest in butterflies.

Although visitors' attitudes regarding deontological status, legal compliance, and political activism were relatively high, half of them still purchased butterfly souvenirs. The high number of visitors who purchased these souvenirs corresponded with their preferences toward certain butterfly attributes. Visitors' preferences for the attributes of butterfly souvenirs turned out to be related to four values: display, authenticity, quality, and utility. Visitors' particular interest in butterflies with authenticity value would undoubtedly impact not only economic benefits but also threaten the environmental sustainability of butterflies. This threat could be further compounded because most visitors did not know about the prohibition of catching and purchasing some butterfly species. Additionally, visitors received incorrect information and thereby adopted a loose tolerance to butterfly trading, influencing their behavior and preferences. Therefore, it is advised that the park manager apply ecotourism practices that not only prioritize the tourism business, but also provide environmental education for visitors. 
Trading butterfly souvenirs began many years ago, involves numerous stakeholders, and has become a main attraction for park visitors. Since the problem of the butterfly trade is quite longstanding and complicated, solutions such as simply stopping the practice might not be easy. To reduce its negative impacts, it is necessary to implement careful and strategic management plans and appropriate policies.

Initial steps should start with identifying the species of butterflies which need immediate protection as priority species. For example, regarding legal protections, the level of endemicity and the integrity of the butterfly population in the park should be considered. Based on the priorities identified, regulations should be adopted and later communicated to visitors in the form of announcements, leaflets, and banners, etc. Given the large species variety of butterflies, the species that are classified as priorities for protection should be publicized in detail, including their scientific as well as local names. Priority species should be displayed in pictures or photos to make it easier for visitors to recognize them. The presence of photographs or images is expected to inspire visitors with high levels of political activism to help campaign against the butterfly trade. Given the high deontological values of visitors, it is necessary to educate them by displaying detailed information about the prioritized species. For instance, information on the functions and benefits of the butterfly in nature and its habitat conditions might shape the deontological values of visitors.

The high preference of visitors for originality and authenticity with respect to butterfly souvenirs should also receive attention. Park management is expected to educate and convince visitors to purchase butterfly souvenirs in which at least some parts come from other butterflies, at the same time encouraging catchers and artisans to pick up and utilize butterfly carcasses when making souvenirs. However, there has been a lack of similar research in other butterfly-themed parks. Thus, further research should be conducted in order to determine whether if there are significant differences among destinations. This will consequently help park managers to establish strategic management plans for destinations.

Author Contributions: Conceptualization, F.A. and S.K.; methodology, F.A. and S.K.; software, F.A. and Y.J.; validation, F.A., I.A.P., Y.J. and S.K.; formal analysis, F.A., Y.J., and S.K.; investigation, F.A.; resources, F.A.; data curation, F.A. and Y.J.; writing-original draft preparation, F.A. and I.A.P.; writing—review and editing, Y.J. and S.K.; visualization, F.A., Y.J., and S.K.; supervision, I.A.P. and S.K.

Funding: This research received no external funding.

Conflicts of Interest: The authors declare no conflict of interest.

\section{References}

1. Swanson, K.K.; Timothy, D.J. Souvenirs: Icons of meaning, commercialization and commoditization. Tour. Manag. 2012, 33, 489-499. [CrossRef]

2. Amin, F.A.; Bonjar, M.K. Baluch Women's Participation in Handicrafts Production and Its Impact on Tourism Development. Case Study: Nok Abad Region. J. Radix Int. Educ. Res. Consort. 2015, 4, 1-24.

3. Tjoa, A.M.; Wagner, R.R. The Role of Handicraft Production and Art in Tourism and its Presentation in the Internet. In Proceedings of the 5th International Conference on Information and Communication Technologies, Istanbul, Turkey, 21-23 Janurary 1998.

4. Raymond, J. The Impact of Tourism on Handicraft Production in Nova Scotia. Master Thesis, The University of Manitoba, Winnipeg, MB, Canada, 1978.

5. Nason, J.D. Tourism, Handicrafts, and Ethnic-Identity in Micronesia. Ann. Tour. Res. 1984, 11, 421-449. [CrossRef]

6. Kwon, M. One Place after Another: Site-Specific Art and Locational Identity; Massachusetts Institute of Technology: London, UK, 2002; p. 218.

7. Mustafa, M. Potential of sustaining handicrafts as a tourism product in Jordan. Int. J. Bus. Soc. Sci. 2011, 2, $145-152$.

8. Lukić, T.; Stojanović, T.; Đerčan, B.; Živković, M.B.; Živković, J. The Geographical Aspects of Traditional Handicrafts in Serbia. Eur. Res. 2015, 100, 747-758. [CrossRef] 
9. Erlina, B.; Hapsari, R.A.; Ramasari, R.D. Outlook for Tapis fabric as traditional crafts Lampung society in the indication geography legal protection. In Proceedings of the Third International Conference on Law, Business and Governance, Bandar Lampung, Indonesia, 20-21 May 2016.

10. Swanson, K.K.; Horridge, P.E. Travel motivations as souvenir purchase indicators. Tour. Manag. 2006, 27, 671-683. [CrossRef]

11. Hengky, S.H. Beneficial Images: Batik handicraft tourism in Yogyakarta, Indonesia. Bus. Econ. Res. 2014, 5, 11-23. [CrossRef]

12. Bui, H.T.; Jolliffe, L. 11 Souvenir Production and Attraction: Vietnam's Traditional Handicraft Villages. Tour. Souvenirs Glocal Perspect. Margins 2013, 33, 161.

13. Ko, T.G. The issues and implications of escorted shopping tours in a tourist destination region: The case study of Korean package tourists in Australia. J. Travel Tour. Mark. 2000, 8, 71-80. [CrossRef]

14. Park, M.K. Social and cultural factors influencing tourists' souvenir-purchasing behavior: A comparative study on Japanese "Omiyage" and Korean "Sunmul". J. Travel Tour. Mark. 2000, 9, 81-91. [CrossRef]

15. Vadhanasindhu, P.; Yoopetch, C. A Study on Factors Affecting Purchasing Decision on Thai Silk Handicraft of International Tourists in Bangkok. In Proceedings of the First UTCC Graduate Research Conference 2006: "Multi-disciplinary Research Papers", Bangkok, Thailand, 26-28 May 2006; pp. 489-497.

16. Timothy, D.J. Aspect of Tourism 23: Shopping Tourism, Retailing and Leisure; Channel View Publications: Bristol, UK, 2005.

17. Peters, K. Negotiating the 'Place' and 'Placement' of Banal Tourist Souvenirs in the Home. Tour. Geogr. 2011, 13, 234-256. [CrossRef]

18. Lasusa, D.M. Eiffel Tower key chains and other pieces of reality: The philosophy of souvenirs. Philos. Forum 2007, 38, 271-287. [CrossRef]

19. UNESCO; ITC. Crafts and the International Market: Trade and Customs Codification. In Proceedings of the International Symposium on Crafts and the International Market: Trade and Customs Codification, Manila, Philippines, 6-8 October 1997.

20. Sanchez-Medina, P.S.; Corbett, J.; Toledo-Lopez, A. Environmental Innovation and Sustainability in Small Handicraft Businesses in Mexico. Sustainability 2011, 3, 984-1002. [CrossRef]

21. Vargas, M.P.B.; Andel, T.V. The use of hemiepiphytes as craft fibres by indigenous communities in the colombian amazon. A J. Plantspeopleand Appl. Res. 2005, 3, 243-260. [CrossRef]

22. Klooster, D.J. Toward adaptive community forest management: Integrating local forest knowledge with scientific forestry. Econ. Geogr. 2002, 78, 43-70. [CrossRef]

23. Barnes, L.J. The Overt Illegal fur Trade in Kathmandu, Nepal; Inverness Research Associates: Inverness, CA, USA, 1989.

24. Boppre, M.; Vane-Wright, R.I. The Butterfly House Industry: Conservation Risks and Education Opportunities. Conserv. Soc. 2012, 10, 285-303. [CrossRef]

25. Lemelin, R.H. Finding Beauty in the Dragon: The Role of Dragonflies in Recreation and Tourism. J. Ecotour. 2007, 6, 139-145. [CrossRef]

26. New, T.R. Butterfly ranching: Sustainable use of insects and sustainable benefit to habitats. Oryx 2009, 28, 169-172. [CrossRef]

27. Carvalho, J.C.M.; Mielke, O.H.H. Trade of butterfly wings in Brazil and its effects upon the survival of the species. In Proceedings of the 13th International Congress of Entomology, Moscow, Russia, 2-9 August 1971.

28. Higginbottom, K. Wildlife Tourism: Impacts, Management and Planning; Higginbottom, K., Ed.; Cooperative Research Centre for Sustainable Tourism: Queensland, Australia, 2004.

29. Larsen, T.B. Butterfly art in Africa-Conservation implications. Butterfly Conserv. News 1996, 61, 12-14.

30. Ardahanlığlu, Z.R.B.; Özhanc1, E. Tourism Pressure in Protected Areas; Butterflies Valley Case. Procedia Soc. Behav. Sci. 2014, 120, 386-393. [CrossRef]

31. Wang, H.; Shao, S. Study on the Eco-tourism Environment Protection Based on the External Theory. Asian Soc. Sci. 2009, 5, 13-17. [CrossRef]

32. Putri, I.A.S.L.P. Pengaruh aktivitas pariwisata terhadap keragaman jenis dan populasi kupu-kupu di Taman Nasional Bantimurung Bulusarang. J. Penelit. Hutan Dan Konserv. Alam 2016, 13, 101-118. [CrossRef]

33. Putri, I.A.S.L.P. Handicraft of butterflies and moths (Insecta: Lepidoptera) in Bantimurung Nature Recreation Park and its implications on conservation. Biodiversitas J. Biol. Divers. 2016, 17, 823-831. [CrossRef] 
34. Menteri Kehutanan. Surat Keputusan Nomor 398/Menhut-II/2004 tentang Perubahan Fungsi Kawasan Hutan pada Kelompok Hutan Bantimurung - Bulusaraung Seluas \pm 43.750 (empat puluh tiga ribu tujuh ratus lima puluh) Hektar terdiri dari Cagar Alam Seluas $\pm 10.282,65$ (sepuluh ribu dua ratus delapan puluh dua enam puluh lima perseratus) Hektar, Taman Wisata Alam Seluas \pm 1.624,25 (seribu enam ratus dua puluh empat dua puluh lima perseratus) Hektar, Hutan Lindung Seluas $\pm 21.343,10$ (dua puluh satu ribu tiga ratus empat puluh tiga sepuluh perseratus) Hektar, Hutan Produksi Terbatas Seluas \pm 145 (seratus empat puluh lima) Hektar, dan Hutan Produksi Tetap Seluas \pm 10.355 (sepuluh ribu tiga ratus lima puluh lima) Hektar terletak di Kabupaten Maros dan Pangkep, Provinsi Sulawesi Selatan menjadi Taman Nasional Bantimurung Bulusaraung; Departemen Kehutanan Republik Indonesia: Jakarta, Indonesia, 2004.

35. Asriady, D. Pengembangan Wisata Taman Nasional Bantimurung Bulusaraung. Available online: http: / / www.tn-babul.org/index.php?option=com_content\&view=article\&id=312:pengembangan-wisatataman-nasional-bantimurung-bulusaraung\&catid=49:artikel (accessed on 12 August 2017).

36. Bantimurung-bulusaraung National Park. Rencana Pengelolaan Jangka Panjang Taman Nasional Bantimurung Bulusaraung Periode 2008-2027 Kabupaten Maros dan Pangkep Provinsi Sulawesi Selatan; Balai Taman Nasional Bantimurung Bulusaraung: Maros, Indonesia, 2008; p. 132.

37. Triwin. Menilik dari Dekat Persiapan Taman Nasional Bantimurung Bulusaraung Menuju Penangkar Kupu-kupu Terbesar di Indonesia. Available online: www.ekowisata.orgdalamhttp://www.tn-babul.org/ index.php?option=com_content\&view=article\&id=455:menilik-dari-dekat-persiapan-taman-nasionalbantimurung-bulusaraung-menuju-penangkar-kupu-kupu-terbesar-di-indonesia\&catid=49:artikel (accessed on 12 August 2017).

38. Handayani, S.A.; Kadriansyah; Bachri, S.; Ismail, T.; Sukmawati; Jasmin, E.I.; Shagir, K.J. Keanekaragaman Jenis kupu-kupu Papilionidaer Taman Nasional Bantimurung Bulusaraung; Balai Taman Nasional Bantimurung Bulusaraung: Maros, Indonesia, 2015.

39. Handayani, S.A. Taman Nasional Bantimurung Bulusaraung "The Kingdom of Butterfly?". Available online: http:/ / www.tn-babul.org/index.php?option=com_content\&view=article\&id=311\%3Atamannasional-bantimurung-bulusaraung-the-kingdom-of-butterfly- \&catid=49\%3Aartikel\&Itemid=195 (accessed on 12 August 2017).

40. Hadwen, W.L.; Hill, W.; Pickering, C.M. Icons under threat: Why monitoring visitors and their ecological impacts in protected areas matters. Ecol. Manag. Restor. 2007, 8, 177-181. [CrossRef]

41. Juvan, E.; Dolnicar, S. Measuring environmentally sustainable tourist behaviour. Ann. Tour. Res. 2016, 59, 30-44. [CrossRef]

42. Kim, A.K.; Weiler, B. Visitors' attitudes towards responsible fossil collecting behaviour: An environmental attitude-based segmentation approach. Tour. Manag. 2013, 36, 602-612. [CrossRef]

43. Cochrane, J. Indonesian national parks-Understanding leisure users. Ann. Tour. Res. 2006, 33, 979-997. [CrossRef]

44. Elliot, A.J.; Covington, M.V. Approach and Avoidance Motivation. Educ. Psychol. Rev. 2001, 13, 73-92. [CrossRef]

45. Rumbaugh, D.M.; King, J.E.; Beran, M.J.; Washburn, D.A.; Gould, K.; Kornell, N.; Scaturo, D.J.; Haig, B.D.; Schvaneveldt, R.W.; Barton, B.K.; et al. Approach and Avoidance Motivation. In Encyclopedia of the Sciences of Learning; Seel, N.M., Ed.; Springer US: Boston, MA, USA, 2012; pp. 286-288.

46. Moutinho, L. Consumer Behaviour in Tourism. Eur. J. Mark. 1987, 21, 5-44. [CrossRef]

47. Albayrak, T.; Caber, M. Examining the relationship between tourist motivation and satisfaction by two competing methods. Tour. Manag. 2018, 69, 201-213. [CrossRef]

48. Fodness, D. Measuring Tourist Motivation. Ann. Tour. Res. 1994, 21, 555-581. [CrossRef]

49. Kamri, T.; Radam, A. Visitors' Visiting Motivation: Bako National Park, Sarawak. Procedia Soc. Behav. Sci. 2013, 101, 495-505. [CrossRef]

50. Jeong, Y.; Zielinski, S.; Chang, J.-S.; Kim, S.-I. Comparing Motivation-Based and Motivation-Attitude-Based Segmentation of Tourists Visiting Sensitive Destinations. Sustainability 2018, 10, 3615. [CrossRef]

51. Rid, W.; Ezeuduji, I.O.; Pröbstl-Haider, U. Segmentation by motivation for rural tourism activities in The Gambia. Tour. Manag. 2014, 40, 102-116. [CrossRef]

52. Andreu, L.; Kozak, M.; Avci, N.; Cifter, N. Market Segmentation by Motivations to Travel. J. Travel Tour. Mark. 2005, 19, 1-14. [CrossRef] 
53. Leonidou, L.C.; Leonidou, C.N.; Kvasova, O. Antecedents and outcomes of consumer environmentally friendly attitudes and behaviour. J. Mark. Manag. 2010, 26, 1319-1344. [CrossRef]

54. Leonidou, L.C.; Coudounaris, D.N.; Kvasova, O.; Christodoulides, P. Drivers and Outcomes of Green Tourist Attitudes and Behavior: Sociodemographic Moderating Effects. Psychol. Mark. 2015, 32, 635-650. [CrossRef]

55. Chan, R.Y.K.; Wong, Y.H.; Leung, T.K.P. Applying Ethical Concepts to the Study of "Green" Consumer Behavior: An Analysis of Chinese Consumers' Intentions to Bring their Own Shopping Bags. J. Bus. Ethics 2007, 79, 469-481. [CrossRef]

56. Garcia-Rosell, J.-C.; Moisander, J. Ethical Dimensions of Sustainable Marketing-A Consumer Policy Perspective. Eur. Adv. Consum. Res. 2007, 8, 210-215.

57. Ando, A.W. Waiting to be protected under the endangered species act: The political economy of regulatory delay. J. Law Econ. 1999, 42, 29-60. [CrossRef]

58. Bohlen, G.; Schlegelmilch, B.; Diamantopoulos, A. Measuring ecological concern: A multi-construct perspective. J. Mark. Manag. 1993, 9, 415-430. [CrossRef]

59. Gil De Zúñiga, H.; Puig-I-Abril, E.; Rojas, H. Weblogs, traditional sources online and political participation: An assessment of how the internet is changing the political environment. New Media Soc. 2009, 11, 553-574. [CrossRef]

60. Litirell, M.A.; Baizerman, S.; Kean, R.; Gahring, S.; Niemeyer, S.; Reilly, R.; Stout, J. Souvenirs and Tourism Styles. J. Travel Res. 2016, 33, 3-11. [CrossRef]

61. Kong, W.H.; Chang, T.Z. Souvenir Shopping, Tourist Motivation, and Travel Experience. J. Qual. Assur. Hosp. 2016, 17, 163-177. [CrossRef]

62. Slone, T.H.; Orsak, L.J.; Malver, O. A comparison of price, rarity and cost of butterfly specimens: Implications for the insect trade and for habitat conservation. Ecol. Econ. 1997, 21, 77-85. [CrossRef]

63. Wurzinger, S.; Johansson, M. Environmental Concern and Knowledge of Ecotourism among Three Groups of Swedish Tourists. J. Travel Res. 2016, 45, 217-226. [CrossRef]

64. Kil, N.; Holland, S.M.; Stein, T.V. Structural relationships between environmental attitudes, recreation motivations, and environmentally responsible behaviors. J. Outdoor Recreat. Tour. 2014, 7-8, 16-25. [CrossRef]

65. Kadir, A.W.; Purwanto, R.H.; Poedjirahajoe, E. Analisis Kondisi Sosial Ekonomi Masyarakat Sekitar Taman Nasional Bantimurung Bulusaraung, Provinsi Sulawesi Selatan (Socio-economic Analysis of Community Around Bantimurung Bulusaraung National Park, South Sulawesi Province). J. Mns. Dan Lingkung. 2012, 19, 1-11.

66. Bantimurung-bulusaraung National Park. Rencana Strategis Taman Nasional Bantimurung Bulusaraung 2015-2019; Balai Taman Nasional Bantimurung Bulusaraung: Maros, Indonesia, 2015; p. 63.

67. Waluyo, H.; Sadikin, S.R.; Gustami; Whiting, P. An economic valuation of biodiversity in the karst area of Maros, south Sulawesi, Indonesia. Biodiversity 2005, 6, 24-26. [CrossRef]

68. Tejada, J.J.; Punzalan, J.R.B. On the Misuse of Slovin's Formula. Philipp. Stat. 2012, 61, 129-136.

69. Boxall, P.C.; Adamowicz, W.L. Understanding heterogenous preferences in random utility models: A latent class approach. Environ. Resour. Econ. 2002, 23, 421-446. [CrossRef]

70. Turner, L.W.; Reisinger, Y. Shopping satisfaction for domestic tourists. J. Retail. Consum. Serv. 2001, 8, $15-27$. [CrossRef]

71. Bank, T.W. GDP Per Capita (Current US\$). Available online: https://data.worldbank.org/indicator/ny.gdp. pcap.cd (accessed on 5 March 2019).

(C) 2019 by the authors. Licensee MDPI, Basel, Switzerland. This article is an open access article distributed under the terms and conditions of the Creative Commons Attribution (CC BY) license (http://creativecommons.org/licenses/by/4.0/). 